Gut, 1983, 24, 427-432

\title{
Autoantibodies to gut hormone secreting cells as markers of peptide deficiency
}

\author{
H W JONES, R LENDRUM, JANET M MARKS, RITA MIRAKIAN, \\ G F BOTTAZZO, D L SARSON, AND S R BLOOM
}

From the Department of Gastroenterology, Freeman Hospital, and the Department of Dermatology, Royal Victoria Infirmary, Newcastle upon Tyne, the Department of Immunology, Middlesex Hospital, London, and Royal Postgraduate Medical School, London

SUMMARY Autoantibodies reacting with endocrine cells in the gastrointestinal mucosa were found by indirect immunofluorescence in 22 out of 268 sera $(8.2 \%)$ obtained from patients with coeliac disease, Crohn's disease, ulcerative colitis, irritable bowel syndrome, and from subjects without bowel disease. A double immunofluorescence technique showed that the autoantibodies reacted with cells secreting gastric inhibitory polypeptide (glucose dependent insulinotropic polypeptide, GIP), secretin, somatostatin or enteroglucagon. Most sera contained antibodies against more than one cell type. Neither the presence of a particular antibody nor the pattern of antibody combinations appeared to be specific for any diagnostic category. The mean plasma GIP concentrations, however, both fasting and two hours after a test meal, were significantly lower in subjects with GIP cell autoantibodies. Thus gut hormone cell autoantibodies may be markers of impaired hormone secretion.

Organ specific circulating autoantibodies which can be detected by indirect immunofluorescence are frequently associated with disturbed endocrine function - for example, autoimmune thyroid disease, Addison's disease, type I insulin dependent diabetes, etc. Recent advances in immunocytochemistry have established the existence of an extensive endocrine system within the mucosa of the gastrointestinal tract. The possibility of humoral autoimmunity directed against this endocrine tissue was suggested by reports of autoantibodies against a number of gut hormone cells in diabetes mellitus (pancreatic glucagon and somatostatin cells), atrophic gastritis (gastrin cells), and coeliac disease (duodenal GIP and secretin cells) ${ }^{1-3}$ but no systematic search has been reported in other chronic bowel disorders. Autoantibodies against peptide secreting cells throughout the gut were therefore sought in sera from patients with a variety of intestinal disorders and in subjects without evidence of bowel disease.

Address for correspondence and reprints: Dr R Lendrum, Department of Gastroenterology, Freeman Hospital, Newcastle upon Tyne.

Received for publication 12 July 1982

\section{Methods}

SUBJECTS

Serum samples were tested from a total of 268 subjects (115 men, 153 women). The diagnoses in these were established by accepted clinical, radiological, or histological criteria and included coeliac disease (43 patients), dermatitis herpetiformis ( 24 patients, 10 of whom also had coeliac disease), Crohn's disease (47), ulcerative colitis (65), and irritable bowel syndrome (44). The remaining 45 subjects included 30 patients without evidence of past or present bowel disorder and 15 healthy members of hospital staff. Follow up serum samples after intervals of three to 18 months were obtained from 20 subjects in whom antibodies to gut endocrine cells were detected in the initial samples.

\section{TISSUE SUBSTRATES}

'Normal' intestinal mucosa was obtained at operation from patients of blood group $\mathrm{O}$ undergoing surgery because of pathology, usually neoplasia, in adjacent bowel. Samples of duodenum, jejunum, ileum, and colon from several different donors were used (Table 1). The intestinal 
Table 1 Tissue substrates from patients of blood group $O$

\begin{tabular}{ll}
\hline Mucosa & Indications for surgery \\
\hline Duodenum (1) & Gastric carcinoma \\
Duodenum (3) & Pancreatic carcinoma \\
Jejunum (2) & Mesenteric ischaemia \\
Jejunum (2) & Pancreatic carcinoma \\
Ileum (3) & Colonic carcinoma \\
Ileum (2) & Ileal conduit \\
Ascending colon (1) & Caecal carcinoma \\
Descending colon (1) & Rectal carcinoma \\
Sigmoid colon (1) & Rectal carcinoma \\
\hline
\end{tabular}

Figures in parentheses show numbers of different donors for each tissue.

mucosa was immediately separated from the underlying muscle, rolled up, snap frozen in melting isopentane, and stored in liquid nitrogen. Human thyroid, stomach and pancreas, and rat liver and kidney were also used in identifying other organ and non-organ specific autoantibodies.

\section{IMMUNOFLUORESCENCE METHODS}

(a) Detection of autoantibodies Test sera were applied for 60 minutes, without being previously diluted, to tissue sections cut at $2-4 \mu \mathrm{m}$. Sections were washed for 20 minutes in buffered saline and sheep fluorescein (FITC) conjugated antihuman whole immunoglobulin, anti-IgG, -IgA, and -IgM (Wellcome Laboratories), or sheep antihuman $\mathrm{C}_{3}$ (Nordic Laboratories) together with fresh normal human serum as a source of complement were applied. Antibody titres were determined by serial doubling dilutions. All sera were tested on mucosa from at least two different donors.

(b) Identification of gut hormone cells A four-layer immunofluorescence technique was used as previously described. ${ }^{1}$ After the sequence described in (a) specific rabbit antisera against porcine GIP, glucagon and vasoactive intestinal polypeptide (VIP), or synthetic secretin and somatostatin (kindly provided by various laboratories as detailed previously) ${ }^{3}$ were applied followed by goat rhodamine (TRITC) conjugated antirabbit immunoglobulin (Wellcome).

\section{SPECIFICITY OF AUTOANTIBODIES}

1 Absorption with specific hormone In order to be certain that the fluorescence was because of antibodies directed against components of the cells other than the hormones themselves, two sera, containing antibodies against GIP cells but not against other cell types, were absorbed at $4^{\circ} \mathrm{C}$ overnight with an excess of pure GIP, to give a final serum concentration of 250000 pmols of GIP per litre. Control sera were absorbed with buffered saline alone. An identical series of experiments was carried out with GIP hormone antiserum at a concentration of four doubling dilutions below endpoint.

2 Inactivation of complement components In order to exclude non-specific complementmediated binding of immunoglobulins to endocrine cells the following two procedures were undertaken before applying sera to frozen sections as described above: (i) Firstly, aliquots of 20 sera containing putative autoantibodies were absorbed at $4^{\circ} \mathrm{C}$ overnight with an excess of antihuman $C_{1 q}(200 \mu l$ serum, $20 \mu \mathrm{l}$ anti- $\mathrm{C}_{1 \mathrm{q}}$; DAKO, Mercia Borcades Ltd batch No $129 \mathrm{~A}$, titre 11280 ). Control sera were absorbed with $20 \mu \mathrm{l}$ of buffered saline. (ii) Secondly, to inactivate heat labile components of complement, aliquots of 20 positive sera were heated to $56^{\circ} \mathrm{C}$ for one hour.

\section{METABOLIC RESPONSES}

As subjects with GIP cell autoantibodies were the most numerous it was decided to assess their metabolic responses to a test meal. Eleven subjects with GIP cell autoantibodies were compared with 11 subjects without these antibodies. There were nine women and two men in each group matched for age and disease (Table 2). After a fasting basal blood sample a $2225 \mathrm{KJ}$ 'standard breakfast' ${ }^{4}$ was given and further blood was obtained after 30 and 120 minutes. Blood for hormone assay was collected in heparinised tubes containing aprotinin (400 kallikrein inactivating units per $\mathrm{ml}$ of blood). The plasma was separated within 15 minutes and stored at $-20^{\circ} \mathrm{C}$ until assayed without knowledge of the antibody results. Simultaneous samples were analysed for whole blood glucose concentration using glucose oxidase. Hormone profiles were compared in the matched pairs using a two-tailed paired $t$ test.

Table 2 Numbers of sera tested in each diagnostic category and numbers containing autoantibodies

\begin{tabular}{lll}
\hline & \multicolumn{2}{l}{ Numbers of sera tested } \\
\cline { 2 - 3 } & Total & Ab positive \\
\hline Coeliac disease & 43 & $4(2)$ \\
Dermatitis herpetiformis (DH) & 14 & 1 \\
Coeliac disease with DH & 10 & 1 \\
Crohn's disease & 47 & $4(3)$ \\
Ulcerative colitis & 65 & $2(1)$ \\
Irritable bowel syndrome & 44 & $5(3)$ \\
Without evident bowel disease & 45 & $5(2)$ \\
Total & 268 & 22 \\
\hline
\end{tabular}

Figures in parentheses show the number of pairs of patients who underwent metabolic studies. 


\section{HORMONE RADIOIMMUNOASSAY}

Plasma GIP and insulin were measured by conventional radioimmunoassays. ${ }^{5}$ The GIP antiserum was raised to pure natural porcine material and fully detected both big and little human GIP though showing no cross reaction with other peptides.

\section{Results}

\section{IMMUNOFLUORESCENCE}

Twenty-two of the 268 sera $(8 \cdot 2 \%)$ contained antibodies which reacted with mucosal cells in the duodenum and jejunum having a distribution and morphology suggestive of endocrine cells. Twenty of these sera were tested against all the tissue substrates collected (Table 1) and gave positive results with the appropriate mucosa in all cases. The remaining two sera were tested on duodenum from two donors only, both giving identical results. Three of these 22 sera also reacted with cells in the colonic mucosa. No fluorescence reactions were obtained on ileal mucosa; all the sera were tested on the ileal mucosa from two donors and many of them on an additional three substrates. The antibodies in all the 22 positive sera were of IgG class and there was an additional IgM component in eight of them. No reactions were obtained using anti-IgA conjugate. Results were unaffected by the previous heating of serum to $56^{\circ} \mathrm{C}$ for one hour or by overnight absorption with anti- $\mathrm{C}_{1 \mathrm{q}}$. Using anti- $\mathrm{C}_{3}$ conjugate all of 18 sera tested were shown to fix complement after the addition of fresh normal human serum. Antibody titres using polyvalent anti-human immunoglobulin ranged from $1: 4$ to $1: 32$. Further serum samples obtained from 20 of the subjects three to 18 months later produced identical fluorescent patterns and titres. These antibodies did not correlate with any of the clinical diagnoses included in this study and occurred in each of the groups tested (Table 2). There was no discernible difference in disease activity or duration of disease in patients with gut endocrine cell antibodies compared with patients of the same diagnostic category but without antibodies. Subjects without bowel disease but with gut hormone cell autoantibodies included three healthy volunteers, one patient with chronic bronchitis, and one patient with mild dementia.

Four layer immunofluorescence confirmed that these antibodies were reacting with mucosal endocrine cells. Most of the sera contained antibodies against more than one cell type (Table 3 ). The pattern of the reacting cells among the 22 sera again appeared to be independent of diagnostic category. Overnight absorption with pure GIP failed to affect the fluorescence produced with two sera containing GIP cell autoantibodies while abolishing the fluorescence obtained using a GIP hormone antiserum on frozen sections.

METABOLIC RESPONSES TO A STANDARD MEAL Plasma GIP levels in subjects with and without GIP cell autoantibodies are shown in Fig. 1. The mean basal plasma level was significantly lower in antibody positive subjects $(6 \cdot 82 \pm 0.71 \mathrm{pmol} / \mathrm{l})$ than in antibody negative subjects $(10.82 \pm 1.02 \mathrm{pmol} / \mathrm{l}$; $\mathrm{p}<0.02$ ); a significantly lower mean value was also obtained 120 minutes postprandially in the subjects with antibodies $(21 \cdot 10 \pm 2 \cdot 14 \mathrm{pmol} / \mathrm{l}$, compared with $26.64 \pm 1.9 \mathrm{pmol} / \mathrm{l} ; \mathrm{p}<0.02)$. Values 30 minutes postprandially were not significantly different between the two groups.

Plasma insulin responses did not differ in the two groups (Fig. 2).

Whole blood glucose levels were lower in the fasting samples for patients with GIP cell antibodies than in those without but postprandial values were similar in the two groups (Fig. 3). No fasting blood sugar value exceeded $6 \mathrm{mmol} / \mathrm{l}$.

\section{Discussion}

Despite earlier reports that autoantibodies occur against duodenal GIP and secretin cells in coeliac disease and tropical sprue $\mathrm{e}^{3}$ the significance of such antibodies has not been determined. No previous systematic search for autoantibodies reacting with peptide secreting cells throughout the gut in different gastrointestinal diseases has been reported. This study confirms the existence of a system of humoral autoimmunity directed against several different gut peptide secreting cells. The

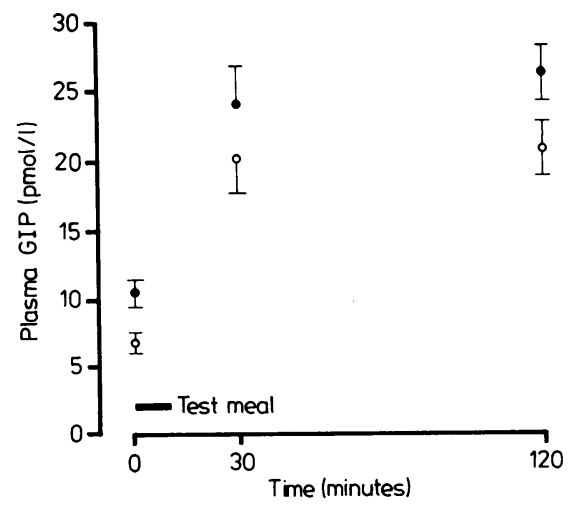

Fig. 1 Plasma GIP response to a standard test meal in subjects with $(\bigcirc)$ and without $(\bullet)$ GIP cell autoantibodies. 


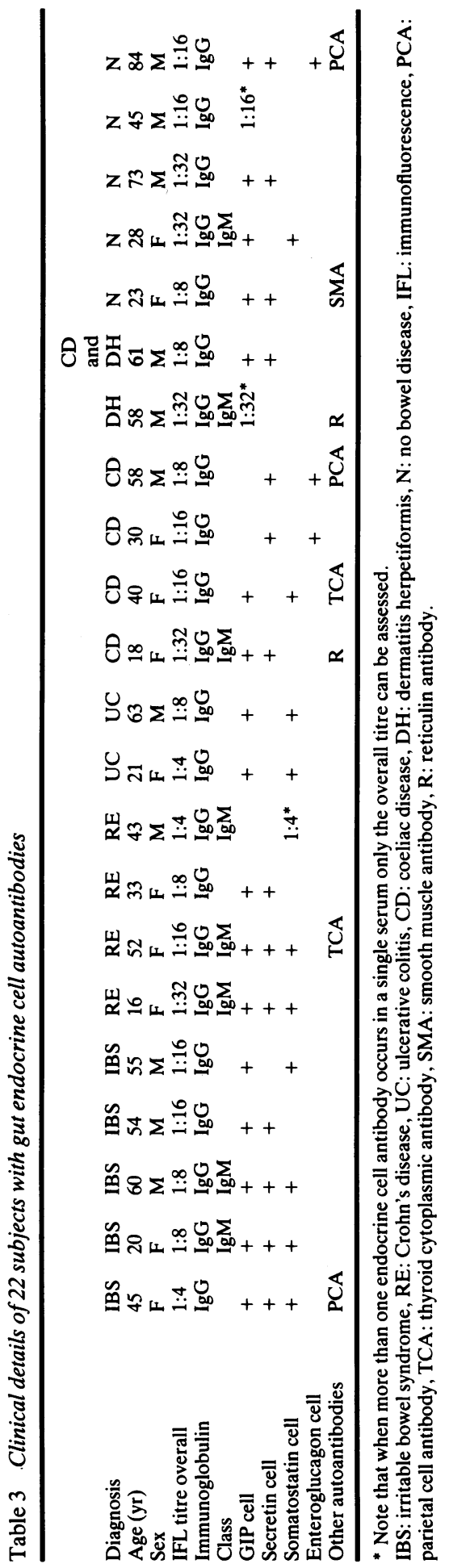




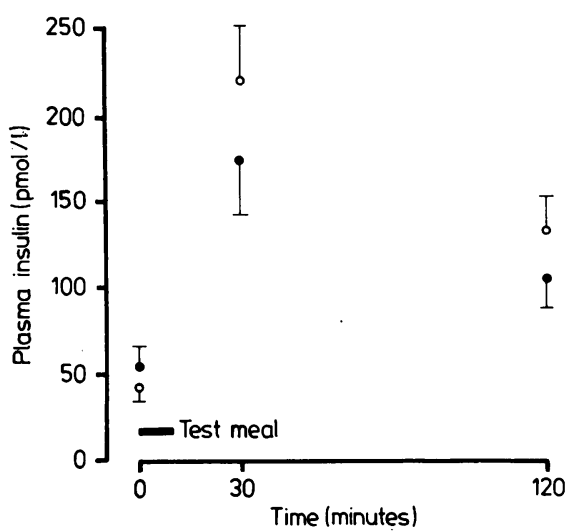

Fig. 2 Plasma insulin response to a standard test meal in subjects with (०) and without $(\bullet)$ GIP cell autoantibodies.

antibodies are not directed against the secreted hormone as shown by the failure to abolish GIP cell fluorescence after absorption with pure GIP. In common with other endocrine autoantibodies, therefore, they appear to react with structural cytoplasmic components.

It has been suggested that hormone secreting cells of the gastrointestinal mucosa may bind immunoglobulins in a non-specific manner, mediated via the $\mathrm{C}_{1 \mathrm{q}}$ fraction of complement, producing fluorescence on fixed sections. ${ }^{6}$ This does not explain the results in the present study because heating the sera to $56^{\circ} \mathrm{C}$, or absorption with anti- $\mathrm{C}_{1 \mathrm{q}}$, failed to abolish fluorescence on frozen sections.

As it was possible to observe varying combinations of reacting cell types using sera from different patients it is likely that distinct antigens are present in each of the different hormone secreting cells. A

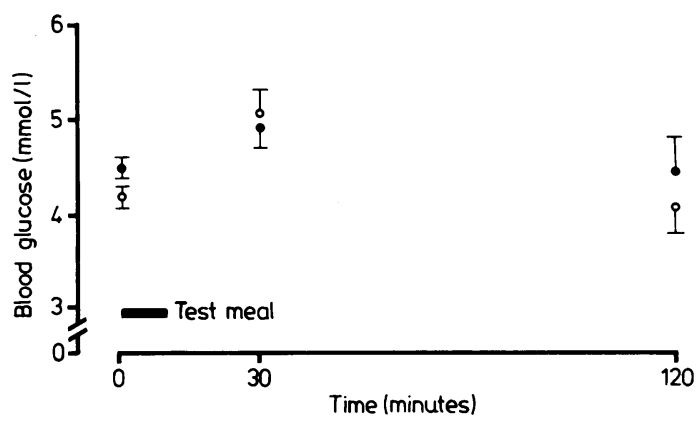

Fig. 3 Blood glucose levels after a standard test meal in subjects with (०) and without (•) GIP cell autoantibodies. similar observation has been made in relation to pancreatic islet ${ }^{1}$ and pituitary cells. ${ }^{7}$

The finding that the mean plasma GIP concentrations are lower in the group of patients with GIP cell antibodies suggests that the antibodies may be markers for a pathological process affecting those cells. The assessment of any possible cytotoxic effect of these autoantibodies must await the development of techniques for the accurate separation and quantification of gut peptide cells. ${ }^{8}$ By determining metabolic responses in subjects with isolated peptide cell abnormalities, however, it is likely that information at least comparable with that of hormone infusion experiments will be obtained. Likewise, future studies of gut hormone responses should take account of the existence of this autoimmune system.

The concept of GIP as a glucose dependent insulinotropic hormone must be considered. It has been suggested that GIP may play a major part in the enteroinsular response to ingested glucose ${ }^{9}$ and be important in diabetes mellitus, particularly of the type II non-insulin dependent variety. Fasting blood glucose levels, however, were below the accepted value $^{10}$ for a diagnosis of diabetes mellitus in all subjects. It is of interest that among these nondiabetic patients with GIP cell antibodies there was a decreased GIP response to a test meal while the glucose responses and insulin levels did not differ from the control group with no such antibodies. Nevertheless, the possibility remains that the presence of GIP cell autoantibodies may be inportant in patients with established diabetes mellitus.

The present data do not suggest a specific association between the presence of circulating gut endocrine cell antibodies and any of the gastroenterological disorders investigated so far. If the actions of the peptides, however, are mainly at a local level on adjacent cells - that is, paracrine then these antibodies might be expected to provide new insight into the influence of individual cells upon their neighbours. As 'gut hormones' are widely distributed throughout the body - for example, as neurotransmitters ${ }^{11}$ - the possibility remains that the antibodies may reflect pathology in another organ system entirely. Further work is indicated, therefore, to determine their prevalence in other conditions.

We thank Professor Deborah Doniach, Dr A R Morley, and Dr A J Cassells Smith for advice; Drs J Biener, G Boden, R E Chance, P M Dubois, R F Harvey, S I Said, and R H Smith for donations of hormone antisera; the many clinicians who made tissue and serum specimens available; and $\mathrm{Mr} \mathrm{P}$ 
Thompson and Miss Anne Richardson for excellent technical assistance. This research was funded by the Newcastle AHA(T) Scientific and Research Committee and by the British Society of Gastroenterology.

\section{References}

1 Bottazzo GF, Lendrum R. Separate autoantibodies to human pancreatic glucagon and somatostatin cells. Lancet 1976; 2; 873-6.

2 Vandelli C, Bottazzo GF, Doniach D, Francheschi F. Autoantibodies to gastrin producing cells in antral (type B) chronic gastritis. N Engl J Med 1979; 300; 1406-10.

3 Mirakian R, Bottazzo GF, Doniach D. Autoantibodies to duodenal gastric inhibitory peptide (GIP) cells and to secretin $(S)$ cells in patients with coeliac disease, tropical sprue and maturity onset diabetes. Clin Exp Immunol 1980; 41; 33-42.
4 Besterman HS, Bloom SR, Sarson DL et al. Gut hormone profile in coeliac disease. Lancet 1978; 1; 785-8.

5 Sarson DL, Bryant MG, Bloom SR. A radioimmunoassay of gastric inhibitory polypeptide in human plasma. J Endocrinol 1980; 85: 487-96.

6 Buffa R, Solcia E, Fiocca R, Crivelli O, Pera A. Complement mediated binding of immunoglobulins to some endocrine cells of the pancreas. J Histochem Cytochem 1979; 27; 1279-80.

7 Bottazzo GF, Pouplard A, Florin Christensen A, Doniach D. Autoantibodies to prolactin secreting cells of human pituitary. Lancet $1975 ; 2 ; 97-101$.

8 McIntyre RLE, Piris J. A method for the quantification of human gastric $\mathrm{G}$ cell density in endoscopic biopsy specimens. J Clin Pathol 1981; 34; 514-8.

9 Dupre J, Ross SA, Watson D, Brown JC. Stimulation of insulin secretion by gastric inhibitory polypeptide in man. J Clin Endocrinol Metab 1973; 37; 826-8.

10 WHO Expert Committee on diabetes mellitus, 2nd Report. Technical Report Series No 646: 11. Geneva: WHO, 1980.

11 Bloom SR, Polak JM. Gut hormone overview. In: Bloom SR, ed. Gut hormones. Edinburgh: Churchill Livingstone, 1978: 3-18. 